\title{
Naked Subjectivity: Minimal vs. Narrative Selves in Kierkegaard
}

\section{PATRICK STOKES}

University of Hertfordshire, UK

Originally published in Inquiry 53:4 (August 2010) pp.356-382. Please cite the original place of publication in any references.

\begin{abstract}
In recent years a significant debate has arisen as to whether Kierkegaard offers a version of the "narrative approach" to issues of personal identity and selfconstitution. In this paper I do not directly take sides in this debate, but consider instead the applicability of a recent development in the broader literature on narrative identity - the distinction between the temporally-extended "narrative self" and the non-extended “minimal self” - to Kierkegaard's work. I argue that such a distinction is both necessary for making sense of Kierkegaard's claim that we are ethically enjoined to become selves, and can indeed be found in Either/Or and the later The Sickness Unto Death. Despite Kierkegaard's Non-Substantialism, each of these texts speaks (somewhat obliquely) of a "naked self" that is separable from the concrete facticity of human being. In both cases, this minimal self is linked to issues of eschatological responsibility; yet the two works develop very different understandings of 'eternity' and correspondingly divergent accounts of the temporality of selfhood. This complicates the picture of Kierkegaardian selfhood in interesting ways, taking it beyond both narrativist and more standard neo-Lockean models of what it is to be a self.
\end{abstract}




\section{Introduction}

It has long been accepted that Søren Kierkegaard offers a relational, non-substantialist account of what it is to be a self. However, while the critical literature on Kierkegaard has sought to situate Kierkegaard's account of selfhood within the context of his Idealist forebears and contemporaries, ${ }^{1}$ far less has been done to locate Kierkegaard relative to the main strands of contemporary personal identity theory - an important step if we are to evaluate the full extent to which Kierkegaard's work on selfhood remains philosophically relevant. ${ }^{2}$ There has, however, been one important exception in recent years: some Kierkegaard commentators (most notably John J. Davenport and Anthony Rudd) have sought to assign Kierkegaard a place within narrative identity theory, a broad field ranging from avowedly non-realist positions ${ }^{3}$ to strongly realist ones. ${ }^{4}$ Narrativists have offered sensitive and careful readings of Kierkegaard in support of this contention, drawing on Kierkegaard's talk of teleologically-qualified selves acquiring "histories" to argue that Kierkegaardian selves are constituted by a specifically narrative form of continuity. Yet narrative identity theories themselves have come in for significant criticism, ${ }^{5}$ while in Kierkegaard Studies John Lippitt in particular has argued that there are good reasons for being wary both of narrativity in general and of the claim that Kierkegaard himself endorses a narrative account of personal identity. ${ }^{6}$

In this paper, I do not intend to make any claims either way for the veracity or otherwise of narrative identity theory, nor do I wish to claim that Kierkegaard (or any of his relevant pseudonyms) either is or is not a narrativist. Instead, I wish to consider the argument made in some important recent discussions of identity that our self-experience contains both a narrative self and a "minimal self," and show that some version of this distinction is indeed operative in Kierkegaard's two most important texts on the subject of self-constitution. 
However, I will argue that the ways in which the minimal self operates in Either/Or and The Sickness Unto Death differ in crucial respects, in ways that will have significant implications for the attempt to recruit Kierkegaard - rather than just Judge William - to the cause of narrative identity theory.

\section{Selves In and Out of Narrative}

Narrative identity theories vary widely in scope, motivation and underlying metaphysical assumptions, and so speaking of narrative theory in general (as we'll do here) will involve significant over-simplification. The most broadly-stated version of the narrative approach's central thesis would be something like this: the self exists (whether as a real object or fictional construct) as a temporally-extended form of narratively-qualified continuity between psychological and physical events. However, instead of merely determining the conditions under which a self can be said to persist between two different points in time, as most postLockean identity theorists do, narrative theorists generally add the qualification that "we need to think of ourselves as temporally extended wholes."7 Narratives have an overall shape and trajectory, which gives them a unity that goes beyond mere continuity between discrete points in time. The difference between psychological continuity per se and narrative continuity tracks the difference between a narrative and a mere chronicle of events: the former has a shape for which its beginning and end are essential, while the latter simply recounts events between two given points of time. ${ }^{8}$ The Anglo-Saxon Chronicle could begin and end in different years and still be perfectly intelligible as a chronicle, whereas if Beowulf stopped suddenly during the journey to the Mere, it would be a broken narrative, containing a comprehensible sequence of events but only narratively intelligible as a fragment of a larger, lost narrative. It may be that key parts of our life-narratives are inaccessible to us, such as our 
conception, birth and death, ${ }^{9}$ and indeed our entire future is subject to radical and unforeseeable contingencies; but according to the narrativists we must nonetheless think of ourselves as a unified whole. If we want our actions to be intelligible to ourselves, ${ }^{10}$ on this line, then we must see them as embedded in some larger narrative, which in turn will make sense with reference to yet larger narratives; this assumes that at some ultimate (if inaccessible) level there will be a narrative that holds together and makes sense of our entire life. Let's call this the whole life intelligibility thesis.

Several objections to the narrative approach have been offered, but here I want to concentrate on one particular problem: the apparent bifurcation of the self as a narrative whole and the self as a present, conscious agent. Consider this articulation of the whole life intelligibility thesis from Rudd:

When I ask whether “particular aspects of [my] life hang together” I can’t help but do so against some (more or less explicit) sense of what my "life as a whole" is; after all, it is the whole of me that will be, say, moving to America or getting married, not just an aspect of my life! ${ }^{11}$

But if my self is a temporally-extended narrative, this won't be quite right: my entire narrative is not moving to America. Rather, a portion of my narrative - maybe a short one, maybe one that extends right to the end - will now take place in America (we might then ask whether my moving to America makes good sense, or specifically narrative sense, in the context of my life). My narrative doesn't change location in the way my body does; we can ask where a person is now, but not where his narrative is now. ${ }^{12}$

We look like running afoul of something analogous to a standard objection to fourdimensionalist metaphysics of persons. Four-dimensionalists claim that while "person stages" 
may be said to exist at any one time, a person only exists across time as an aggregate of person stages. ${ }^{13}$ But as Marya Schechtman notes, whatever we could point to as a "person stage" will be a talking, rational, self-referring agent with at least some degree of temporal duration; in short, on any reasonable construal of the properties that a person has, personstages will themselves count as persons - which means we explain the identity conditions of one person at the cost of positing a second person occupying the same space. ${ }^{14}$ And a similar fissure opens up in the moving-to-America example: in the declaration "I am moving to America tomorrow" the referent of "I" is distinct from the narrated life that includes time in America. The self-as-narrator and the self-as-narrative have here come apart. Or putting the same point somewhat differently, we can ask, with Daniel D. Hutto, "How can we be the products of acts of narration, if in some sense we are responsible for the production of the relevant self-making narratives?"15

This problem is only amplified when the whole life intelligibility thesis is added to what Galen Strawson has called the "ethical narrativity thesis," which he claims narrativists frequently conflate with the distinct "psychological narrativity thesis." ${ }^{16}$ It is one thing to argue that the self is the (fictional or nonfictional) protagonist of the stories we tell. It is another thing to claim that a narratively unified life is also a psychologically more pleasant one. It is yet a third thing to claim that it is morally desirable to attain narrative unity, possibly as a necessary condition of attaining stable virtuous dispositions. "To judge a life as morally shabby or as failing to realize its telos," as Lippitt reminds us, "is not - at least, not without considerable further argument - the same as judging it as incoherent or unintelligible." ${ }^{17}$ Yet narrativists like Alasdair MacIntyre tend to run together at least the first and third claims listed above, and possibly the second as well. 
In the context of Kierkegaard, this conflation might be excusable, in that the Kierkegaardian self is already a morally-qualified concept, not a normatively-neutral substratum from which we deduce or infer moral facts such as responsibility, entitlement etc. Thus those commentators Lippitt dubs "MacIntyrean Kierkegaardians"18 find support for the claim that narrative unity and the ethical are internally related. ${ }^{19}$ It's certainly the case that Kierkegaard claims we are ethically enjoined to become ourselves (e.g. EO, 2:177/SKS 3, 173); ${ }^{20}$ but as Rudd admits, the claim that we both are and are ethically enjoined to become selves (found both in Kierkegaard and in narrativist theories that accept both the whole life intelligibility thesis and the ethical narrativity thesis) looks somewhat paradoxical: "how can there be an ethical project of becoming a Self unless there is already a Self to take on that project?"21 Considerations of this sort force Rudd to acknowledge that Kierkegaard's account implies two distinct senses of selfhood: a weak sense in which a self is just a "self-conscious rational being" and a stronger sense in which selfhood is "an ideal to be realized" by that subject. ${ }^{22}$

This is one point on which Rudd and Lippitt are in agreement: "anyone capable of responding to such a call must already [be] a self in some more minimal sense."23 This implies a split between the self-as-agent and the self as a narratively-unified, diachronically-extended entity that we are normatively enjoined to become. Narrativists are at pains to repudiate any sort of Cartesian, substantialist picture of the self as a "bare locus" of experience, precisely because it is hard to see how such a bare locus could support the things we apparently care about in personal identity. What we care about in e.g. survival is, they rightly point out, no featureless token of identity but "a distinct personality with his or her own unique character, history, way of being." 24 Yet Rudd has to concede that this rich, narratively expressed self is distinguishable from "a mere first-person perspective" which, though a necessary condition for having a self, can, in cases such as brain damage, detach from the self as narrative 
entity. ${ }^{25}$ Rudd insists that "A Self is not a bare I plus some extra ingredient; a bare I is a drastically diminished Self,",26 but this doesn't dissolve their conceptual (and sometimes experiential) distinguishability. Elsewhere, Rudd draws on Strawson's distinction between the self as a phenomenally-given locus of experience (Strawson's "self*": the mental entity that I experience myself as being right now) and the human being that I take myself to be, arguing that becoming a self in the full sense involves the self* acquiring a sense of identification with that human being. ${ }^{27}$ I agree entirely both with this way of setting up the human/self dynamic and the way in which they are taken to interrelate through an appropriative process of affective identification. ${ }^{28}$ But such an appropriation involves the self as appropriator, whose existence must somehow be irreducible to the practical identity that it fashions out of the "stuff" of a human life. To be a self is therefore more than just being a narratively-interconnected series of events, or even (as in Rudd's argument), a narrativelyextended "mental substance." A "bare I" may be "diminished" qua practical agent to the extent that it is cut off from its history and context, but in another sense every practical agent is also a "bare I" as well.

\section{Minimal vs. Narrative Selves}

The distinction between a "bare I" or first-person-perspective and a temporally-extended self has been made by philosophers coming at the problem of selfhood from a somewhat different angle, one informed by both the phenomenological tradition and developments in the cognitive sciences. This is the distinction between the narrative or autobiographical self (a self-image or self-conception that is diachronically constituted) and a core or minimal self, the present locus of consciousness which relates to the diachronically-extended narrative self. $^{29}$ 
Antonio Damasio distinguishes between core consciousness, which "provides the organism with a sense of self about one moment - now - and about one place - here," and extended consciousness which "provides the organism with an elaborate sense of self - an identity and a person, you or me, no less - and places that person at a point in individual historical time, richly aware of the lived past and of the anticipated future, and keenly cognizant of the world beside it. ${ }^{, 30}$ Core consciousness arises in response to each distinct "pulse" of consciousness and is therefore confined to the present moment; accordingly, the core self, the entity that core consciousness senses itself to be, is only "a transient entity, ceaselessly re-created for each and every object with which the brain interacts." ${ }^{31}$ Extended consciousness, by contrast, brings the past and future into view in the present moment and so gives rise to a temporallyextended autobiographical self. ${ }^{32}$ Like the self endorsed by narrativists, this autobiographical self contains a sense of diachronic extension, while both responding to and re-evaluating the past and evolving in response to its anticipated future. ${ }^{33}$ The Core and Autobiographical selves are strongly, indeed "architecturally" connected, ${ }^{34}$ yet remain at least conceptually distinguishable, not least by virtue of their asymmetrical relationship of dependency: impairments in extended consciousness, such as severe anterograde amnesia, can leave core consciousness unscathed, whereas the destruction of the core self entails the destruction of the autobiographical self as well. ${ }^{35}$ And mirroring the claim made by some narrativists that we are somehow anthropologically geared to seek unity and coherence, Damasio claims that evolutionary pressures have lead to a situation where the core and autobiographical selves interact to ensure unity of the subject: "more than one self per organism is not a good recipe for survival.",36

Dan Zahavi claims that this distinction between the core/minimal self and the autobiographical/narrative self answers the problem we noted above, namely, that there must 
already be some sort of self, something with a distinctive first-person perspective, to be able to articulate an identity in narrative terms. ${ }^{37}$ Note, however, that the minimal self as presented by Zahavi, Damasio and (in a different form) Strawson is something more than a mere linguistic capacity for self-reference. The ability to use the first-person pronoun at all depends upon a pre-linguistic phenomenal property of experiencing oneself $a s$ a self in all moments of consciousness. Zahavi argues that the minimal self as a sense of "mineness" (Heideggarian Jemeinigkeit) built into all moments of intentional consciousness is a key feature of the work of all major figures in the phenomenological tradition from Husserl onwards. ${ }^{38}$ For the phenomenologists, all moments of consciousness are qualified by an "invariant dimension of first-personal givenness in the multitude of changing experiences," a tacit sense that the experience is an experience for someone. ${ }^{39}$ Zahavi stresses that this is not to suggest that there is some isolated, inner self, like a Cartesian mental substance ${ }^{40}$ first-personal givenness and the sense of self it engenders is a feature of our everyday consciousness, not something we uncover in worldless introspection.

Zahavi argues, compellingly, that any successful account of narrative selfhood will need to presuppose this minimal, core sense of self, the feeling of "mineness," in order to get off the ground at all. It's worth adding, though, that the notion of a property of phenomenal "mineness" (rather than the purely formal Kantian version) built into consciousness can be traced further back than Husserl - as far back, at least, as Kierkegaard's unfinished manuscript Johannes Climacus, or, De Omnibus Dubitandum Est. As I've argued elsewhere ${ }^{41}$ this work's equation of consciousness with "interestedness" (interesserethed) amounts to positing a phenomenal property of personal involvement in consciousness, a nonthematised sense of self-referentiality built into the very structure of thought. That interestedness is a state to be achieved, rather than a given, marks an important point of 
difference between Kierkegaard and the $20^{\text {th }}$ century phenomenological tradition; but if Kierkegaard posits a sense of phenomenal self-referentiality even at the level of basic consciousness, this suggests that his work will contain something like a "minimal self" as currently understood. And if Kierkegaard truly is a narrative theorist in the way that MacIntyrean Kierkegaardians want to claim, his account will, plausibly, also require some version of the minimal self, to explain how selves can be both the agent and product of their own self-constituting activity. But can such a distinction be found in Kierkegaard? I will argue that it can, but that the specific forms that it takes will have some interesting implications.

\section{Kierkegaardian Psychological Continuity and Narrative}

Kierkegaard's two most sustained discussions of selfhood - Either/Or Part II and The Sickness Unto Death - certainly have much to offer those seeking to recruit Kierkegaard to the cause of narrative identity, not least in their emphases on how the self comes to acquire itself in the form of a history, and their developmental anthropology whereby selves come to progressively fuller understandings of themselves. Judge William, 'author' of the second half of Either/Or, claims that for a human being to become a self is for her to attain a particular type of psychological continuity through time, without which her entire personality collapses into atomistic incoherence:

Or can you think of anything more appalling than having it all end with the disintegration of your essence into a multiplicity, so that you actually become several, just as that unhappy demoniac became a legion, and thus you would have lost what is 
the most inward and holy in a human being, the binding power of the personality? (EO, 2:160/SKS 3, 158)

A human being in such a state, regarded diachronically, amounts to no more than a sequence of psychological events, devoid of any internal coordinating principle. The subject who simply bounces from passion to passion, mood to mood, with no underlying projects or commitments to coordinate these events, is reduced to these moments. In Judge William's terminology, such a subject is not a self; instead of achieving selfhood, the personality (personlighed, "personal-ness") "withers away in atrophy" (EO, 2:163/SKS 3, 160). What is lost in such a case is the internal coherence of the personality across time, that which unifies it and gives the subject what Judge William calls "continuity with the past and the future" (EO, 2:263/SKS 3, 250). Obtaining such continuity requires an integration of consciousness (EO, 2:177/SKS 3, 173) that 'submerges' the raw material of psychological life into a consolidated identity via a process of choice (EO, 2:163/SKS 3, 160). This submersion amounts to adopting all these psychological moments as a totality for which the self is answerable, thereby regarding its concretion as a temporally-extended ethical task rather than as a simple chronicle of psychological events:

The individual, then, becomes conscious as this specific individual with these capacities, these inclinations, these drives, these passions, influenced by this specific social milieu, as this specific product of a specific environment. But as he becomes aware of all this, he takes upon himself responsibility for it all. He does not hesitate over whether he will take this particular thing or not, for he knows that if he does not do it something much more important will be lost. (EO, 2:251/SKS 3, 239)

In this way, the factical content of 'immediate' personality is changed into what Davenport calls "volitional character constituted by patterns of earnest caring," converting a sequence of 
disconnected moments into "self-guiding patterns" intelligible in terms of volitional commitments. ${ }^{42}$

It may be objected that there is nothing terribly narrative about this conception of selfconstitution; indeed Judge William's account of self-consolidating choice has also been likened to ostensibly non-narrative philosophical conceptions of the self such as Bernard William's notion of "ground projects" and Harry Frankfurt's account of higher-order volitions as self-constituting. ${ }^{43}$ Moreover, the Judge's talk of achieving "continuity" of personality, and of the subject finding herself "in continuity with the past and the future" of her "concrete personality," might initially sound rather neo-Lockean. Contemporary neoLockeans speak of various forms of psychological continuity or connectedness as preserving personal identity across time; why mightn't Judge William's self-constituting 'choice' be regarded simply as securing such psychological continuity by giving the personality a stable, diachronically-extended volitional framework? Why invoke the stronger concept of "narrativity" here at all?

MacIntyrean Kierkegaardians can reply that William's developmental anthropology makes his account of selfhood teleological in character, in a way straightforward psychological continuity theories are not. ${ }^{44}$ Selves acquire a "history" in a narrative sense (the Danish historie means both "history" and "story") that provides a teleological understanding of where we are going in terms of where we have been. The contents of immediate selfhood only become a history when the subject "acknowledges identity with himself" and that he "is the person he is only through this history" (EO, 2:216/SKS 3, 207, my emphasis). And essential to this history is development: lives such as those of mystics, which merely oscillate between ecstatic highs and frightful "flat moments," have "movement, but not development" and so only acquire a history "in the same sense that one speaks of the history of a plant" 
(EO, 2:242/SKS 3, 231). The ethical self constitutes itself by engaging in commitments such as marriage, which require temporal extension and must unfold in time for their full meaning to be evident. So it seems clear that William departs from straightforward psychological continuity theory, in ways that seem friendly, at least, to contemporary narrative theory.

The Sickness Unto Death is also concerned with self-relation and continuity, and, like the Judge, Anti-Climacus regards selfhood as a product of a particular mode of self-relation. Anti-Climacus distinguishes between the human being (mennenske) - a synthesis of opposed elements such as finitude and infinitude, physical and mental - and the self (selv). The self is "spirit," a task presented to the human being - "Every human being is a psychical-physical synthesis intended to be spirit" (SUD, 43/SKS 11, 158) - and is constituted when the human being "relates to itself" 45 and simultaneously to "the power that established it" (SUD, 14/SKS 11, 130). Like Judge William's self, the Anti-Climacan self takes responsibility for its entire life in its concretion, and turns the immediate psychological material it finds itself to be into an ethically-qualified task. The self is not so much a bare pinpoint of consciousness as a lifelong totality that relates to itself in a self-integrating, self-constituting way - which, initially at least, sounds quite close to both William and contemporary narrativism.

In such moments, Kierkegaard seems to have come a long way from Cartesianism: the Kierkegaardian self is not a persisting immaterial substance but a dynamic interrelation of psychological and physical elements. But as we've seen, narrative identity theories seem to require something like a "minimal self" that relates itself to the factical self. And here again, we find ourselves facing the same question: what is it that relates to itself in its concretion (in Either/Or) or itself in its human synthesis (Sickness Unto Death)? As Alastair Hannay notes, a key assumption of Sickness Unto Death, at least, is that while concrete personality is essential to selfhood, "human beings are peculiar among other beings by not being 
exhaustively identified by finite properties. There is an irreducible particularity, an 'I,' for which each 'definite' collection of properties is its own collection." 46 The problem is how we are to understand this irreducible particularity within the context of Either/Or and The Sickness Unto Death, when both are so insistent on the self as concrete and socially and historically situated. Hannay goes on to speak of this particularity as a mere "vantage point" that human beings can take upon themselves, while Davenport's highly nuanced and sophisticated reading of Either/Or seems to leave almost no room for the minimal self at all. Davenport explicitly identifies the self with the totality of the volitional character in a way that is clearly meant to avoid any whiff of Substantialism. Following Hannay, ${ }^{47}$ Davenport insists on two "levels of character: the outer and the inner" operative in Judge William's moral psychology; but for Davenport, this must be understood as an internal relation within the dispositional and volitional structure itself: there "is not a set of character-traits that the self has as accidental properties; rather this character is the self." 48 There is no sense in Davenport's picture of a self distinct from that structure that takes a position towards it. This finds expression in the claim that "at the level of our deep self or core narrative," a discriminable moment of decisive, self-constituting choice (or a moment of transition from the aesthetic to the ethical spheres) "can be only an imaginary abstraction."49

Rudd, too, insists that " $[\mathrm{t}]$ he self is not some isolatable thing, independent of all these [psychological] characteristics; it is what is made manifest in the common style or manner of being in the world that they express." ${ }^{, 50}$ Rudd does allow for a "minimal sense of personal identity established by the continuance of this particular first-person perspective" ${ }^{\natural 1}$ and accordingly a "more-than-Humean Self; one that can stand back from the flux of events and take a stance towards it,",52 but it's not clear whether Rudd sees this as something like a minimal self (with a distinctive phenomenal character) or simply a function of the reflexive 
properties of what he calls the "expressive substance" of the self. In any event, it has long been part of Rudd's interpretation of Kierkegaard, at least, that his work involves "rejecting, or at least qualifying, the disengaged idea of the pure autonomous self, distinct from all social roles, relationships, and commitments." ${ }^{, 53}$ The minimal self, in these narrativist interpretations, plays a very minimal role indeed.

\section{The Naked Self}

There are moments in Either/Or that seem to confirm that the self that distinguishes itself from its historical and psychological makeup can, at most, only be an abstraction rather than some distinctive feature of our self-experience. Judge William holds that only through appropriating our facticity (including our personality), rather than distinguishing ourselves from it, do we attain selfhood:

There was a sect of Hussites who thought that in order to become a normal human being one had to go around naked like Adam and Eve in Paradise. In our day we not infrequently encounter people who in the spiritual sense teach the same thing - that one becomes a normal human being by going stark naked, which can be done by taking off one's entire concretion. But this is not the way it is. In the act of despair, the universal human being came forth and now is behind the concretion and emerges through it. [...] Every person, if he so wills, can become a paradigmatic human being, not by brushing off his accidental qualities, but by remaining in them and ennobling them. But he ennobles them by choosing them. (EO, 2:261-62/SKS, 3, 249)

This is the process Davenport describes: the self takes up a position from within regarding the "accidental qualities" it finds itself to be, rather than somehow abstracting itself out of them. 
And yet elsewhere, such a wholesale separation from the self's concretion is precisely what William seems to describe:

...when the passion of freedom is awakened, it is jealous of itself and by no means allows what belongs to a person and what does not to remain unspecified and confused. Therefore, at the first moment of choice the personality seemingly emerges as naked as the infant from the mother's womb; at the next moment it is concrete in itself, and a person can remain at this point only through an arbitrary abstraction. He remains himself, exactly the same that he was before, down to the most insignificant feature, and yet he becomes another, for the choice penetrates everything and changes it. Thus his finite personality is now made infinite in the choice, in which he infinitely chooses himself." (EO, 2:223/SKS 3, 213; emphasis added)

William's emphasis here, clearly, is on the self's coming to possess itself in its facticity, not on any assertion of a bare, featureless "I" beneath the accidental layers of psychological history and accretion. Indeed we're earlier told that the "moment of deliberation" in which the self can be indifferent to what it chooses is, like the Platonic moment, "actually not at all, and least of all in the abstract sense in which you wish to hold onto it; and the longer one stares at it, the smaller it is" (EO, 2:163/SKS 3, 160). Michelle Kosch reads William as claiming (in line with Kierkegaard's other pseudonyms) that the moment of choice is not an introspectible event; like Climacus' "leap," she claims, such a moment of transition can only appear as in the past or yet to come. ${ }^{54}$ Yet in referring to the emergence of the "naked self" William seems to posit some point of transition where the subject has shaken off everything it immediately took itself to be - its social roles, proclivities of character and disposition - but not yet willed itself back into its concretion. William calls this initial moment of choice 
"complete isolation" in which "in choosing myself, I separate myself from my relations to the whole world, until in this separation I end in an abstract identity" (EO, 2:240/SKS 3, 229).

What William wants to warn against is the danger of trying to remain in this state of isolation (which is precisely the detachment affected by the "ironist" described in The Concept of Irony), ${ }^{55}$ completely withdrawn from the world and attaining only an "abstract" perfection; instead, the self needs to immediately regain its concretion through a "repentance [which] places the individual in the closest connection and the most intimate relation with an outside world" (EO, 2:241/SKS 3, 230). Looked at from the perspective of this moral urgency, the moment of choice has to be regarded as infinitesimally small, for the time spent in a state of deliberative non-commitment is itself an object of repentance. ${ }^{56}$ The transition to the ethical life requires a final moment of departure from the non-ethical life, but for ethical reasons this moment must be minimized as much as possible: stalling there only compounds the subject's guilt.

The seemingly paradoxical notion that the self must understand itself as something separate from its history, dispositions and social relationships, and yet relate to this concretion as that which it is, recurs several times in Kierkegaard's work. In Sickness Unto Death, a work concerned precisely with how the self relates to itself in its synthetic concretion, we are told that the person of immediacy must distinguish himself from his social context and psychological history if he is to attain selfhood. Here, Anti-Climacus echoes Judge William in tellingly familiar terms: the man of immediacy may, to a certain extent, have "separated his self from externalities, because he has a dim idea that there may even be something eternal in the self" (SUD, 55/SKS 11, 170), and yet:

He has no consciousness of a self that is won by infinite abstraction from every externality, this naked abstract self, which, compared with immediacy's fully dressed 
self, is the first form of the infinite self and the advancing impetus in the whole process by which a self infinitely becomes responsible for its actual self with all its difficulties and advantages." (SUD 55/SKS 11, 170, emphasis added)

Once again, the "naked" self appears, a self that is teleologically enjoined to take responsibility for the human being that it is, becoming a fully conscious and responsible ethical agent, but which is nonetheless on some level distinguishable from the human being it identifies with. The despairing attempt to be nothing but this purely negative freedom and to foreswear what Davenport calls 'the 'own self' which the ethically responsible person chooses to 'put on"' will foreclose the possibility of being a truly ethical self, for it would make all commitments arbitrarily reversible. ${ }^{57}$ In this form of despair, the self uses its "infinite form," its capacity to detach and distinguish itself from its environment, history and psychological makeup to try (and ultimately fail) to create itself ex nihilo rather than starting with the concretion in which it finds itself embedded (SUD, 68/SKS 11, 182). For both AntiClimacus and Judge William, free human beings have - and in order to become selves must have - a way of referring to or thinking about themselves as something distinguishable from their externalities and particulars; but a human being that uses this power to decline its history or its situation fails to become a self. To take off one's concretion and leave it off is to be a complete non-entity (EO, 2:256/SKS 3, 244); instead, truth lies in the "identity" of the factors of "isolation" and "continuity" (EO, 2:262/SKS 3, 249).

Still, the passages cited above could be used to support a reading whereby the "naked self" is essentially just an abstraction, or perhaps a somewhat poetic way of describing the human capacities for self-reference or spontaneous self-reflection. What they seem to lack is the distinctive phenomenal content that Zahavi points to in declaring that the minimal self is not a mere abstraction. ${ }^{58}$ As noted above, I think that Kierkegaard does in fact have an account of 
a phenomenal property answering to the sense of "first-personal givenness" characteristic of the minimal self. But instead of revisiting the phenomenology of "interest" that I mentioned there, here I will instead outline the distinctive eschatological role that the naked self plays in both Either/Or and Sickness Unto Death, and show that in the latter work at least, this implies a minimal self that is experienced as more than a mere abstraction.

\section{Continuity and Eschatology}

The complex role of the naked self in both works can be seen in their respective discussions of the (despairing) desire to become someone else. Both pseudonyms diagnose a problem at the heart of such a desire: the person who wishes they could acquire the history, properties and projects of some other person nonetheless imagines that such an acquisition would somehow leave their identity intact. William tells us that one who forms the desire to be completely changed in all his particulars "is nevertheless continually of the opinion that he would be himself even if everything were changed" and that "there is something within him that in relation to everything else is absolute, something whereby he is who he is even if the change he achieved by his wish were the greatest possible" (EO, 2:214/SKS 3, 206). He imagines the future scenario as if it would still be him in the future, just in radically altered life-circumstances, and perhaps even with a totally different personality. Is such a thought coherent? Other philosophers have doubted it, ${ }^{59}$ and it certainly sounds suspiciously like a substantialist picture in which a featureless but identity-preserving Cartesian ego passes from one factical set to another. William, too, is adamant that the subject is wrong to think that "he could be changed continually and yet remain the same, as if his innermost being were an algebraic symbol that could signify anything whatever it is assumed to be" (EO, 2:215/SKS 3, 206). The subject makes a grave mistake in thinking that she could surrender her entire 
concretion and still be herself; the only way to be herself is to choose herself in that concretion. Anti-Climacus deploys the same thought-experiment and seems to make the same point:

The man of immediacy does not know himself, he quite literally identifies himself only by the clothes he wears, he identifies having a self by externalities (here again the infinitely comical). There is hardly a more ludicrous mistake, for a self is indeed infinitely distinct from an externality. So when the externals have completely changed for the person of immediacy and he has despaired, he goes one step further; he thinks something like this, it becomes his wish: What if I became someone else, got myself a new self. Well, what if he did become someone else? I wonder whether he would recognize himself. (SUD, 53/SKS 11, 169)

The claim here is that someone who only knows herself as the externalities she immediately is would not be able to recognize herself if those externalities changed completely. And that sounds like a perfectly respectable narrativist or neo-Lockean claim: if I try to envision a version of myself deprived of my body, personality, name, job and set of social relations, what's left to enable me to see that person as being continuous with me in any interesting respect? What, if we rule Cartesian ego-substances out of court, could make that person $m e$ ? We seem drawn to the Parfitian conclusion that there is no underlying "deep further fact" about identity underlying these factors.

So it's fortunate, then, that according to Anti-Climacus such "ludicrous" things as becoming someone else never happen. But just two pages later, we find this:

The question of immortality has often occupied him, and more than once he has asked the pastor whether there is such an immortality, whether one would actually recognize 
himself again - something that certainly must be of very particular interest to him, since he has no self. (SUD, 56/SKS 11, 171)

Kierkegaard describes Anti-Climacus as a Christian "on an extraordinarily high level," (JP, $6431 /$ SKS 22,128 ) so we can fairly comfortably assume that he takes the doctrine of personal immortality seriously, whether as a literal metaphysical fact or as something that we must live as if it is real. Tamara Monet Marks has recently argued that much of Kierkegaard's work on the topic of immortality is an attempt to show the reader just what is at stake in believing orthodox Christian doctrines such as the thoroughly anti-modern notion of bodily resurrection. ${ }^{60}$ In the Christian Discourses Kierkegaard insists that immortality is real, but that "Immortality is not a continued life, a continued life as such in perpetuity, but immortality is the eternal separation between the righteous and the unrighteous; immortality is no continuation that results as a matter of course but a separation that results from the past" (CD, 205/SKS 10, 214). ${ }^{61}$ This might sound like a denial of an afterlife as such, but the phrase "results from the past" points to the sense in which salvation or damnation always at least appear as futural; and accordingly, what the passage just quoted seems to emphasize is eternal life's radical discontinuity from our current earthly existence. ${ }^{62}$

But this raises an important question: if immortality takes us beyond all concrete social relations and psychological properties, then selves who are composed of psychological or physical forms of continuity (of whatever sort and in whatever combination) have nothing in them that could pass into the afterlife and still be them. Traditional doctrines about personal immortality, where these are taken seriously, have always been problematic for the neoLockean tradition, ${ }^{63}$ but they present just as serious a problem for the narrative theorist who takes it that selves are narratives: can narratively-unified life-stories go to hell? (For that matter, can characters, life-views or ground projects?). Post-MacIntyrean commentators have 
tended to see Kierkegaardian teleology in fundamentally Aristotelian terms, noting the sense in which Kierkegaard also shares with Augustine and Aquinas a belief that "that virtues are qualities of character connected to the attainment of beatitude as the final end and highest good of human life." ${ }^{64}$ In that sense, the thought of a final judgment might amount to the merely heuristic thought of a point in time at which there will no longer be any prospect of attaining such a state of virtue, as Davenport has recently argued: at death, our life acquires "an objective significance that no longer changes, that is eternal [...] at death, our practical identity is eternally what it has become: our leeway-liberty ends and our character is forever fixed. $^{65}$

But even this seems to involve the thought of a perspective outside of the narrative self, one that somehow outlives its earthly constitution. And the more traditional picture of personal posthumous survival seems to require a self that is more than just the sum of its virtues, something that transcends the narrative of earthly life and can be present both here and in the posited eschatological scenario. In pre-modernity, the vehicle of this transcendence would be played by the soul, conceived of as immortal and subject to eternal judgment. That sort of substantialism doesn't seem to be available to Kierkegaard, ${ }^{66}$ yet it's telling that both AntiClimacus and Judge William seem to equate the "naked self" that sees itself as radically distinct from its history and externalities with this bearer of eschatological judgment. William continues his discussion of the person who longs to be someone else as follows:

... at this point I merely want to find the most abstract expression for this "self" that makes him who he is. And this is nothing other than freedom. By this route it is actually possible to present a very plausible demonstration of the eternal validity of the personality. Indeed, even a suicide does not will to do away with his self; he, too, wishes - he wishes another form for his self, and this is why we certainly can find a 
suicide who is very convinced of the immortality of the soul, but whose whole being was so ensnared that he believed he would by this step find the absolute form for his spirit. (EO, 2:214-15/SKS 3, 206)

William continually argues that this minimal self is the basis upon which we can choose ourselves in our "eternal validity" (e.g. EO, 2:211/SKS 3, 203). Anti-Climacus, too, frequently describes the self's coming to see itself as distinct from its environment and brute facts about its personality as its becoming aware of "something eternal" within it. The "naked self" then, the "abstract form" of human freedom, seems inherently bound up with notions of eternality and, by extension, eschatology. Yet if Kierkegaard is - rightly - read as a nonsubstantialist, what is this "something eternal" that is the subject of personal immortality and eternal judgment? When we are told that the immediately-qualified subject has forgotten "his name, divinely understood" (SUD, 33-34/SKS 11, 149), what are we to understand as the referent of such a name?

\section{Eternality and Temporality}

At this point we need to note the divergent understandings of eternality and judgment that characterize Either/Or and The Sickness Unto Death, and their correspondingly different understandings of the temporality of selfhood. Part of the reason Judge William's description of selfhood appeals so much to narrativist Kierkegaardians is that his self is explicitly temporally extended in a historically developmental fashion, one in which the selfconstituting moment of repentance itself becomes a moment in that history:

...the self he chooses has a boundless multiplicity within itself inasmuch as it has a history, a history in which he acknowledges identity with himself. This history is of a 
different kind, for in this history he stands in relation to other individuals in the race and to the whole race, and this history contains painful things, and yet he is the person he is only through this history. (EO, 2:216/SKS 3, 207)

At the moment of self-constituting choice, the self does not construct itself ex nihilo, but instead binds itself to its past and to the human race from which it arises (EO, 2:239/SKS 3, 228); the subject "repents himself back into himself, back into the family, back into the race, until he finds himself in God" (EO, 2:216/SKS 3, 207). On this picture, self-constitution through repentance is the acquiring of a qualitatively new, ethically-charged form of continuity with my past and future. I take ownership and responsibility for both my personal past and the communal past in which I am embedded. ${ }^{67}$ Thus William's self has a robustly inthe-world quality about it; the seemingly worldless minimal self exists for just a tiny moment before re-immersing itself (but with a new form of self-consciousness and volitional coherence) into the flow of concrete social life.

William still uses the language of traditional Christian soteriology; for instance, the selfconstituting choice of myself in my "absolute validity" (EO, 2:219/SKS 3, 209) amounts to discovering "my soul" or "innermost being" (EO, 2:221/SKS 3, 211). But we are told that the phrase "to damage one's soul" is "an ethical expression, and the person who thinks he has an ethical life-view must also think he is able to explain it." (EO, 2:220/SKS 3, 211). What's interesting about the way William uses such apparently religiously-freighted terms as "soul," "judgment" and "eternity" is that he does so in ways that seem to denude them of their eschatological meanings. The admonition respice finem, "think of the end," offered to one whose moral well-being we are concerned for, is for William no memento mori but rather a carpe diem that has nothing deathly about it: "the word finis does not mean death, because even that is not a human being's most difficult task, but life, that there comes a moment when 
in reality the thing to do is to begin to live;" here our concern for our friend's soul is that he will end up "a defective specimen of a human being instead" in this life (EO, 2:327/SKS 3, 308-09).

William is keen to make his aesthetic friend aware that time is running out, but then proposes that through self-constituting choice (such as the commitment to marriage), the self can attain an "eternity" within life. Thus the married man has fought "the most dangerous enemy, which is time" but has "not killed time but has rescued and preserved it in eternity," and so "solve[d] the great riddle, to live in eternity and yet to hear the cabinet clock strike in such a way that its striking does not shorten but lengthens his eternity" (EO 2:138/SKS 3, 137). The "continuity" attained in marriage gives love an inner "eternity" that shields it from the corrosive effects of time. But this eternity, measured out by the hall clock's chime and successive wedding anniversaries, doesn't seem to amount to anything more than open-ended continuity. It's certainly a long way from the eschatological notion of a future judgment after a life is concluded. The ethicist's eternity "does not come afterward, as for the knight, but he has had eternity in time, has preserved eternity in time," an eternity that is to be preferred to that found in "a story from the Middle Ages about a poor wretch who woke up in hell and shouted 'What time is it?' - whereupon the devil answered, 'Eternity!'” (EO, 2:138-39/SKS $3,137)$.

In Sickness Unto Death eternity plays a rather different role, one that, as I've argued elsewhere, forecloses the sorts of continuity that a neo-Lockean would require. ${ }^{68}$ The AntiClimacan conception of the self is robustly theological in character, and thus we are told that "to have a self, to be a self, is the greatest concession, an infinite concession, given to man, but it is also eternity's claim upon him" (SUD, 21/SKS 11, 137). And this "claim" is of a distinctly eschatological sort. Eternity, for Anti-Climacus, refers not to continuity within 
time, but instead to a point at which "the hourglass of temporality" has run out and worldly distinctions such as sex, class, and relative fortune have been dispensed with (SUD, 27/SKS $11,143)$. In this context, eternity is a situation in which one's life as a totality receives a final judgment:

eternity asks you and every individual in these millions and millions about only one thing: whether you have lived in despair or not [...] And if so, if you have lived in despair, then, regardless of whatever else you won or lost, everything is lost for you, eternity does not acknowledge you, it never knew you - or, still more terrible, it knows you as you are known and it binds you to yourself in despair. (SUD, 27-8/SKS $11,143-44)$

To live in despair, for Anti-Climacus, is not to be a self. The despairing person is a human being (a concatenation of physical and psychological factors falling under oppositional descriptions such as infinite and finite, bodily and mental, necessary and free, etc.), but insofar as this concatenation does not relate to itself in a self-constituting way, it is in despair and thus fails to qualify as a self. It is whether the self has attained this status that is at issue in the scenario of eternal judgment: "No matter how much the despairing person avoids it [...] eternity nevertheless will make it manifest that his condition was despair" (SUD, 21/SKS 11, 136).

Both the narrativist and neo-Lockean could try to take all this in their stride. Locke, after all, sought an account of personal identity consistent with the doctrine of a Day of Judgment. ${ }^{69}$ And insofar as narrative selfhood is inherently teleological, the narrative agent sees herself as moving towards some sort of end that will complete the meaning of what has gone before. So it's quite possible to adopt the thought that "eventually I will be subjected to a final, eternal judgment" as the guiding principle of a particular sort of life: one that is teleologically 
directed to seek to end in (in the narratively thick sense of a dénouement) salvation rather than damnation. In that sense, the notion of eternal judgment plays the same role as the goal of a quest in MacIntyre's narrativist account: the achievement to which my particular lifenarrative is leading. ${ }^{70}$ That seems to be a perfectly defensible picture of what narrative selfhood is like. It also seems prima facie consistent with some claims in Sickness Unto Death, such as the assertion that "eternity is the essential continuity [of self-consciousness] and demands this of a person or that he be conscious as spirit and have faith" (SUD, 105/SKS 11, 217). We could interpret this as meaning that the (heuristic) thought of eternal judgment will make us continually self-conscious, such that all moments of our psychological lives are connected by a projective, narratively-qualified sense of self.

However, Anti-Climacus' understanding of eternality has some rather peculiar temporal effects that render this approach problematic. Anti-Climacus distinguishes between two forms of continuity: a merely psychological continuity of sinfulness which acquires "increasingly established continuity" over time (SUD, 106/SKS 11, 218), and the "essential continuity of the eternal through being before God in faith" (SUD, 105/SKS 11, 218). It's the latter continuity, not the former, which constitutes selfhood, thus setting Anti-Climacus apart from straightforward psychological continuity theory. Psychological continuity can survive periods of disruption, such as temporary amnesia or even nightly unconsciousness. But the "essential continuity of the eternal" is quite different, as revealed by a number of seemingly incompatible properties of the Anti-Climacan self. We're told that selves can be lost (SUD, 32-33/SKS 11, 148); yet later it's claimed once selfhood has been achieved we can never completely devolve into selfless spiritlessness (SUD, 62/SKS 11, 177). Elsewhere we're told that some persons "have no self, no self for whose sake they could venture everything, no self before God" (SUD, 35/SKS 11, 151, my emphasis) and yet such a person "has lost his self 
and God" (SUD, 41/SKS 11, 156, my emphasis) - implying something has both been lost and never existed in the first place. Relatedly, when a self is found to be in despair, "it is immediately apparent that he has been in despair his whole life" (SUD, 24/SKS 11, 140), while to be saved from despair is to lose the very possibility of ever being in despair again: "if a person is truly not to be in despair, he must at every moment destroy the possibility" (SUD, 15/SKS 11, 131); these two claims entail that if a self were to re-enter despair (i.e. lose selfhood) then this shows that it was in despair all along (and so was never, in fact, a self). But this clearly contradicts the claim that selves can be lost. We could try to iron these contradictions out, perhaps by dropping the claim that selfhood could be lost (though this would make selfhood a "once-and-for-all" achievement, which is quite at odds with the tenor of Kierkegaard's thought) or modifying it somehow. But there is another option.

The key to resolving this apparent morass of contradictions comes, ironically, from Judge William, who tries to explain the biblical claim that those who have been converted and fall back into paganism can never be saved again (Hebrews 6:4-6) by claiming that we make a mistake when "the eternal is drawn too much into temporal qualifications" (EO, 2:41/SKS 3, 48) such as continuity, duration, completion etc. It seems clear from the discussion above that William himself makes this mistake in his discussion of the eternal as open-ended continuity. In Sickness Unto Death, however, this thought finds expression in the form of the thoroughly present-tense character of despair, which can only be asked about in terms of its presence or absence in the present moment:

Every actual moment of despair is traceable to possibility; every moment he is in despair he is bringing it upon himself. It is always the present tense; in relation to the actuality there is no pastness of the past: in every actual moment of despair the person in despair bears all the past as present in possibility. (SUD, 17/SKS 11, 132-33) 
The judgment that one is in despair and thus not a self - the judgment of eternity - is a judgment of an entire human life, but one based upon its status as it is now. In that sense, we cannot speak of having been a self, only of whether this human being, if exposed to such a judgment right now, is a self. ${ }^{71}$ And in that sense, while human beings may exist across time and can thus be discussed in tenseless or atemporal terms (Octavian in 43BC is Augustus in 27BC, the life of Napoleon spans 51 years, etc.), Anti-Climacan selves cannot be discussed in this way. Thus the apparent contradiction between the "once and for all" character of being saved from despair and the risk of losing an achieved self is dissolved: the only question is whether, confronted with eternity-as-judgment, I am a self now. The "moment" of the present tense is the "moment" (фjeblik) in the specialist sense of the term developed in The Concept of Anxiety: the place where time and eternity intersect (CA, 89/SKS 4, 392).

\section{Implications for Narrative Selfhood}

The narrativist reading of Kierkegaard takes the Kierkegaardian self to be a temporallyextended entity constituted out of psychological and historical factors by the subject's selfnarrating activity. The Minimal Selves of writers like Damasio, Gallagher, and Zahavi, by contrast, have almost no temporal extension. They survive, in Damasio's terms, no longer than the "pulse" of consciousness with which they arise. Thus if we were to view consciousness externally we could be said to have a succession of innumerable fleeting minimal selves from birth to death. ${ }^{72}$ But taking such an external viewpoint on the minimal self largely misses the point, for the minimal self is perhaps better understood as something present in any moment that the self is present, as the present point of consciousness that knows its past and future - its narrative self - as its own, without being reducible to that narrative self. 
That the minimal self lacks temporal extension is also true for both William and AntiClimacus, both of whom posit a "naked self" that seems to correspond to the contemporary minimal self - but each in very different ways. Both are non-substantialists, and so neither takes the self to be something that could exist in a vacuum; yet both also see the minimal self as, essentially, the temporally-emplaced human being's sense of itself as something that transcends its concretion. Yet the way they see this transcendent sense of self interacting with the human's total life diverge markedly.

Judge William's minimal self is like a mathematical vanishing point, an almost extensionless moment between aesthetic immediacy and ethical choice. This "naked" self is the condition for effecting the detachment from what the human being immediately is, is therefore a formal requirement for becoming a narratively-integrated self, but William does not seem keen to assign much in the way of phenomenal character to this minimal self at all. He is more concerned to usher us back into the flow of our psychological life as quickly as possible, albeit with a new ethically-grounded direction and continuity. Thus through the infinitesimally short moment in which the naked self arises, a given set of factical material turns into a self-conscious narrative self extended through time. Judge William's naked self is therefore a feature of these transitional events - a mere staging-post on the journey to a robustly this-worldly conception of ethical self-integration as salvation - rather than an ongoing feature of the subject's self-experience.

The Anti-Climacan naked self, by contrast, is a feature of all self-experience. It too lacks temporal extension, not because it is a vanishing moment within the event of choice, but because the self's entire existence qua self (i.e. as transcending its merely human facticity) is always present-tense. Selves are always "in the moment," not in the aesthetic sense of living with no thought to the past or future, but in the sense that the naked self continually stands 
before the ever-present possibility of eternal judgment as responsible for the narrative self that it both is and transcends. The minimal self at this moment takes final responsibility for the narrative self as what it is to answer for in a projected final judgment, not within time, but outside time.

Thus each work can be understood as offering different accounts of how the minimal and narrative selves interact. But one of these approaches is considerably more compatible with the narrativist project than the other. The locus of Judge William's discussion of selfhood is the self as a site of historical continuity, integrated through a conscious choice back into the factical context from which it momentarily distinguished itself. In that sense it does indeed resemble the sort of narratively-emplotted, socially-embedded self that philosophers like MacIntyre seek to describe. Undeniably, there is much in Sickness Unto Death that also seems prima facie compatible with narrativist readings of Kierkegaard; after all, eternal judgment's concern with the meaning of a whole human life (rather than some portion thereof) has obvious resonances with the whole life intelligibility thesis. However, the resolutely present-tense nature of the Anti-Climacan naked self aligns it far more with the minimal self of Zahavi et al, a sense of presence-to-self that is the condition for the narrative self. The Anti-Climacan self that "rests transparently in the power which established it" (SUD 14/SKS 11, 130) is a point of consciousness that takes eschatological responsibility for a concrete self which it must nonetheless take itself to transcend (as shown by the self's putative survival of death). ${ }^{73}$ William's self attains eternity in time, within its own narrative; Anti-Climacus' self exists in "the moment" - the intersection of time and eternity - and thus has a sense of itself as always-already beyond its own narrative.

Yet this divergence between Judge William and Anti-Climacus may point in a productive direction for utilizing Kierkegaard in discussions of both narrative identity and personal 
identity more broadly. Part of the appeal of narrative theories is that they can better account for the first-personal character of the questions that motivate discussions of personal identity in the first place. As Schechtman puts it, the narrative approach connects more closely with the sorts of concerns personal identity has traditionally been assumed to undergird - survival, moral responsibility, just compensation and egocentric concern - than other neo-Lockean approaches have managed to. At least in part, this is because the narrativist asks a question about characterisation $^{74}$ that seems most appropriately a question about the subject's firstpersonal perspective on the past and future ("Under what description can I characterize this past or future person as being an appropriate object of my self-regarding concern?”), whereas the psychological continuity theorist asks a question about reidentification ("what licenses us in saying self $A$ at $t_{1}$ is the same self as self $B$ at $t_{2}$ ?") which can be asked indifferently from a first or third person perspective. Only recently has Anglophone personal identity theory lead largely by those sympathetic to narrativist claims - begun to appreciate the importance of this irreducibly first-personal aspect of selfhood.

Yet both the reidentification and characterisation questions ultimately ask about the persistence of selves across time. Judge William's ontology of the self is also like that: selves (in the privileged sense) exist from the time the human being begins to make self-constituting choices, and therefore have some at least theoretically specifiable duration. For AntiClimacus, by contrast, it makes sense to talk about the persistence and continuity of human beings, but selves are always present-tense; thus we cannot sensibly assign any duration to them, at least not if we are to be true to the subjective experience of selfhood.

What Anti-Climacus' work suggests is that selves are not mere irreducibly first-personperspectival, but also present-tense-perspectival. This is arguably implicit in problems traditionally discussed in discussions of personal identity theory and the thought experiments 
deployed therein, in which we are confronted by questions such as "will it be me who will be tortured tomorrow after the brain-swap operation?" Narrativists have taught us that we make a serious mistake treating such questions as if they simply concerned the persistence conditions of one object among others, albeit of a rather peculiar type. The question "will I still exist tomorrow?" cannot be replaced with the question "will the same self persist between two given points in time?", for we miss something essential when we try to ask the question impersonally. Anti-Climacus' account suggests a further step: we must attend both to the first-personal character of the question and the temporally-emplaced position from which it is asked.

What we learn from Anti-Climacus' naked self-before-God is that the question of selfhood is a fundamentally existential one, asked by an "I" in the "here and now." The question can be asked neither impersonally nor tenselessly, but only "from within" in the fullest sense of the term. This takes us further away from the standard neo-Lockean picture than narrative theory has done, and indeed further from most metaphysical approaches to personal identity. But it does so in ways that cohere in interesting ways with the contemporary claim that minimal and narrative selves are both essential to selfhood, and that hold out the prospect of advancing the debate in new and challenging directions. ${ }^{75}$

\footnotetext{
${ }^{1}$ See Taylor, M.C. (1980) Journeys to Selfhood: Hegel and Kierkegaard (Berkeley, CA: University of California Press); and Kosch, M. (2006) Freedom and Reason in Kant, Schelling, and Kierkegaard (Oxford: Oxford University Press), pp.200-210.

${ }^{2}$ I have attempted such an orientation in Stokes, P. (2008) "Locke, Kierkegaard, and the Phenomenology of Personal Identity," International Journal of Philosophical Studies, 16:5, pp.645-672, and Stokes, P. (2009) “Anti-Climacus and Neo-Lockeanism: Towards a
} 
Kierkegaardian Personal Identity Theory," in: N.J. Cappelørn, K.B. Söderquist and H. Deuser (Eds.) (2009) Kierkegaard Studies Yearbook 2009, pp.527-555 (Berlin: de Gruyter).

${ }^{3}$ Such as Dennett, D. (1992) “The Self as a Center of Narrative Gravity,” in: F.S. Kessel, P.M. Cole, and D.L. Johnson (Eds.), Self and Consciousness: Multiple Perspectives, pp.103115 (Hillsdale N.J.: Erlbaum).

${ }^{4}$ Such as Rudd, A. (2005) "Narrative, Expression and Mental Substance," Inquiry, 48:5, pp.413-435; Rudd, A. (2007) “Kierkegaard, MacIntyre and Narrative Unity - Reply to Lippitt," Inquiry, 50:5, pp.541-549; and Rudd, A. (2009) “In Defence of Narrative," European Journal of Philosophy, 17:1, pp.60-75.

${ }^{5}$ Examples include Vice, S. (2003) “Literature and the Narrative Self,” Philosophy, 78:1, pp.93-108; Lamarque, P. (2004) “On Not Expecting Too Much from Narrative,” Mind \& Language, 19:4, pp. 393-408; Strawson, G. (2004) “Against Narrativity,” Ratio, XVII:4, pp.428-452; Vollmer, F. (2005) “The Narrative Self," Journal for the Theory of Social Behaviour, 35:2, pp.189-205.

${ }^{6}$ Lippitt, J. (2005) “Telling Tales: Johannes Climacus and 'Narrative Unity,” in: N. J.

Cappelørn and H. Deuser (Eds.) Kierkegaard Studies Yearbook 2005 pp.71-89 (Berlin: de Gruyter); Lippitt, J. (2007) “Getting the Story Straight: Kierkegaard, MacIntyre and Some Problems with Narrative,’ Inquiry, 50:1, pp.34-69. See also Duckles, I. (2007) "Kierkegaard's Irrationalism: a Response to Davenport and Rudd," Southwestern Journal of Philosophy, 36:22, pp.141-151, for a somewhat different set of objections to Davenport and Rudd.

${ }^{7}$ Rudd, "Kierkegaard, MacIntyre and Narrative Unity,” p.545, emphasis added. I am not sure that all narrative theorists would make this stipulation, but it seems - though I cannot argue 
for this here - that any account that lacked this claim would simply be a sub-species of the standard neo-Lockean, 'psychological continuity' approach.

${ }^{8}$ It should be noted that this contrast between chronicle and narrative is not universally accepted; see Ricoeur, P. (1984) Time and Narrative, Vol. I, trans. K. McLaughlin and D. Pellauer (Chicago and London: University of Chicago Press) p.148.

${ }^{9}$ On conception and birth, see Ricoeur, P. (1992) Oneself as Another trans. K. Blamey (Chicago: University of Chicago Press), p.160. For discussions of the problems death poses for narrative theory, see Lippitt, "Getting the Story Straight;" Behrendt, K. (2007) "Reasons To Be Fearful: Strawson, Death, and Narrative,” in: D.D. Hutto (Ed.) Narrative and Understanding Persons, pp.133-153 (Cambridge: Cambridge University Press); Stokes, P. (2006) “The Power of Death: Retroactivity, Narrative, and Interest,” in: R.L. Perkins (Ed.) International Kierkegaard Commentary: Prefaces/Writing Sampler and Three Discourses on Imagined Occasions, pp.387-417 (Macon, GA: Mercer University Press).

${ }^{10}$ This is the motivation J. David Velleman in particular cites for a narrative agency theory (though one that distinguishes between this type of agency and identity across time). See Velleman, J.D. (2006) Self to Self: Selected Essays (Cambridge: Cambridge University Press), pp.203-223.

${ }^{11}$ Rudd, "Kierkegaard, MacIntyre and Narrative Unity” p.544.

${ }^{12}$ We could ask where his narrative "is up to" of course, but saying "his life is up to the part where he moves to America" doesn't seem to be straightforwardly equivalent to saying "he's in America at the moment.”

${ }^{13}$ Lewis, D. (2003) “Survival and Identity,” reprinted in: R. Martin and J. Barresi (Eds.) Personal Identity (Maldon, MA: Blackwell), p.149.

${ }^{14}$ Schechtman, M. (1996) The Constitution of Selves (Ithaca, NY: Cornell), pp.56-60. 
${ }^{15}$ Hutto, D.D. (2007) "Narrative and Understanding Persons," in: Hutto (Ed.) Narrative and Understanding Persons, p.6.

${ }^{16}$ Strawson, “Against Narrativity” p.428

${ }^{17}$ Lippitt, "Getting the Story Straight" p.43

${ }^{18}$ Lippitt, "Getting the Story Straight" p.50

${ }^{19}$ Rudd, "Kierkegaard, MacIntyre and Narrative Unity” p.547

${ }^{20}$ The Kierkegaard's Writings and Søren Kierkegaards Skrifter series will be referred to throughout using the International Kierkegaard Commentary sigla:

CA [1844] (1980) The Concept of Anxiety, trans. R. Thomte in collaboration with A.B. Anderson (Princeton, NJ: Princeton University Press)

$\mathrm{CD}$ [1848] (1997) Christian Discourses and The Crisis and a Crisis in the Life of an Actress, trans. Howard V. Hong and Edna H. Hong (Princeton, NJ:

Princeton University Press)

CUP, 1 [1846] (1992) Concluding Unscientific Postscript to Philosophical Fragments, Vol. 1, trans. Howard V. Hong and Edna H. Hong (Princeton, NJ: Princeton University Press)

EO, 2 [1843] (1995) Either/Or, Vol. 2, trans. Howard V. Hong and Edna H. Hong (Princeton, NJ: Princeton University Press, 1995) JP (1967-1978) Søren Kierkegaard's Journals and Papers, 7 vols., ed. and trans. Howard V. Hong and Edna H. Hong, assisted by Gregor Malantschuk (Bloomington, Indiana and London: Indiana University Press) (citiations give entry number rather than page number)

SUD [1849] (1980) The Sickness Unto Death, trans. Howard V. Hong and Edna H. Hong (Princeton, NJ: Princeton University Press) 
UDVS

[1847] (1993) Upbuilding Discourses in Various Spirits, trans. Howard V.

Hong and Edna H. Hong (Princeton, NJ: Princeton University Press)

SKS 3 [1843] (1997) Søren Kierkegaards Skrifter Bd. 3: Enten - Eller, Anden del, ed.

Niels Jørgen Cappelørn, Joakim Garff, Johnny Kondrup and Finn Hauberg

Mortensen (Copenhagen: Gads Forlag)

SKS 4 [1843-44] (1997) Søren Kierkegaards Skrifter Bd. 4: Gjentagelsen, Frygt og

Baven, Philosophiske Smuler, Begrebet Angest, Forord, ed. Niels Jørgen

Cappelørn, Joakim Garff, Johnny Kondrup and Finn Hauberg Mortensen

(Copenhagen: Gads Forlag)

SKS 7 [1846] (2002) Søren Kierkegaards Skrifter Bd. 7: Afsluttende uvidenskabelig

Efterskrift, ed. Niels Jørgen Cappelørn, Joakim Garff, Jette Knudsen and

Johnny Kondrup (Copenhagen: Gads Forlag)

SKS 8 [1847] (2004) Sфren Kierkegaards Skrifter Bd. 8: En Literair Anmeldelse,

Opbyggelige Taler i Forskjellig Aand, ed. Niels Jørgen Cappelørn, Joakim

Garff, Johnny Kondrup and Alastair McKinnon (Copenhagen: Gads Forlag)

SKS 10 [1848] (2004) Søren Kierkegaards Skrifter Bd. 10: Christlige Taler, ed. Niels

Jørgen Cappelørn, Joakim Garff and Johnny Kondrup (Copenhagen: Gads

Forlag)

SKS 11 [1849] (2006) Søren Kierkegaards Skrifter Bd. 11: Lilien paa Marken og

Fuglen under Himlen, Tvende ethisk religieuse Smaa Afhandlinger,

Sygdommen til Dфden og "Ypperstepraesten" - "Tolderen" - "Synderinden," ed. Niels Jørgen Cappelørn, Joakim Garff, Anne Mette Hansen and Johnny Kondrup (Copenhagen: Gads Forlag) 
SKS 22 (2005) Søren Kierkegaards Skrifter Bd. 22: Journalerne NB11-NB14, ed.

Niels Jørgen Cappelørn, Joakim Garff, Jette Knudsen and Johnny Kondrup (Copenhagen: Gads Forlag)

${ }^{21}$ Rudd, "Narrative, Expression and Mental Substance" p.431; see also Rudd, A. (2008)

"Reason in Ethics Revisited: Either/Or, 'Criterionless Choice' and Narrative Unity,” in: N.J.

Cappelørn and H. Deuser (Eds.) Kierkegaard Studies Yearbook 2008 (Berlin: de Gruyter), p.184, and "In Defence of Narrative" p.70.

${ }^{22}$ Rudd, "Kierkegaard, MacIntyre and Narrative Unity” p.547

${ }^{23}$ Lippitt, "Getting the Story Straight" p.60 n.14

${ }^{24}$ Rudd, "Narrative, Expression and Mental Substance" p.416. This is of course to assume that identity is what we care about in survival, which remains controversial. For a full discussion of this topic, see Martin, R. (1998) Self-Concern: An Experiential Approach to What Matters in Survival (Cambridge: Cambridge University Press).

${ }^{25}$ Rudd, "Narrative, Expression and Mental Substance" p.421

${ }^{26}$ Ibid.

${ }^{27}$ Rudd, "Reason in Ethics Revisited" pp.193-4.

${ }^{28}$ See Stokes, "Locke, Kierkegaard, and the Phenomenology of Personal Identity."

${ }^{29}$ Gallagher, S. (2000) "Philosophical Conceptions of the Self: Implications for Cognitive Science," Trends in Cognitive Sciences, 4:1, pp.14-21; Zahavi, D. (2007) "Self and Other: The Limits of Narrative Understanding," in Hutto (Ed.), Narrative and Understanding Persons pp.179-201.

${ }^{30}$ Damasio, A. (1999) The Feeling of What Happens: Body and Emotion in the Making of Consciousness (London: William Heinemann), p.16

${ }^{31}$ Op.Cit. pp.16-17 
${ }^{32}$ Op.Cit. p. 17

${ }^{33}$ Op.Cit. p. 225

${ }^{34}$ Op.Cit. p. 172

${ }^{35}$ Op.Cit. p. 17

${ }^{36}$ Op.Cit. p. 225

${ }^{37}$ Zahavi, "Self and Other" p.191

${ }^{38}$ Zahavi (2005) Subjectivity and Selfhood: Investigating the First-Person Perspective

(Cambridge MA and London: MIT Press), p.11

${ }^{39}$ Zahavi "Self and Other" p.189

${ }^{40}$ Ibid.

${ }^{41}$ Stokes, P. (2010) Kierkegaard's Mirrors: Interest, Self, and Moral Vision (Hampshire:

Palgrave)

${ }^{42}$ Davenport, J.J. (2001) “Towards and Existentialist Virtue Ethics: Kierkegaard and MacIntyre," in: J.J. Davenport and A. Rudd (Eds.) Kierkegaard After MacIntyre: Essays on Freedom, Narrativity, and Virtue (Chicago and La Salle, IL: Open Court), pp.280-81

${ }^{43}$ Davenport, J.J. (2001) "The Meaning of Kierkegaard's Choice Between the Aesthetic and the Ethical: A Response to MacIntyre," in: Davenport and Rudd (Eds.), Kierkegaard After MacIntyre, p.87; Davenport, “Towards and Existentialist Virtue Ethics” pp.278, 290. See also Rudd, A. (2001) "Reason in Ethics: MacIntyre and Kierkegaard," in: Davenport and Rudd (Eds.), Kierkegaard After MacIntyre, p.138.

${ }^{44}$ Rudd points out that narratives explain teleologically rather than causally in "In Defence of Narrative" p.62

${ }^{45}$ As Kosch notes, the Hongs' "relates itself to itself" is a somewhat misleading translation of forholder sig til sig selv, as forholder sig is here a reflexive verb; "relates to itself" is more 
natural, though it arguably loses something of the original's reflexivity as well. Kosch,

"Freedom and Reason in Kant, Schelling, and Kierkegaard" p.202

${ }^{46}$ Hannay, A. (1998) "Kierkegaard and the Variety of Despair," in: A. Hannay and G.D.

Marino (Eds.) The Cambridge Companion to Kierkegaard (Cambridge: Cambridge

University Press), pp.339-40

${ }^{47}$ Op. Cit. pp.335-36

${ }^{48}$ Davenport, "Towards an Existentialist Virtue Ethics" p.279

${ }^{49}$ Op.Cit. p.307

${ }^{50}$ Rudd, "Narrative, Expression and Mental Substance" p.424

${ }^{51}$ Op.Cit. p. 425

52 Op.Cit. p.429

${ }^{53}$ Rudd, A. (1997) Kierkegaard and the Limits of the Ethical (Oxford: Oxford University Press) p.93

${ }^{54}$ Kosch, "Freedom and Reason in Kant, Schelling, and Kierkegaard" p.213

${ }^{55}$ On irony as detachment, see e.g. Söderquist, K.B. (2007) The Isolated Self: Truth and Untruth in Søren Kierkegaard's On The Concept of Irony (Copenhagen: Reitzel); Cross, A. (1998) "Neither Either Nor Or: The Perils of Reflexive Irony," in: A. Hannay and G.D. Marino (Eds.), The Cambridge Companion to Kierkegaard, pp.125-53 (Cambridge: Cambridge University Press); Kangas, D.J. (2007) Kierkegaard's Instant: On Beginnings (Bloomington and Indianapolis: University of Indiana Press) pp.24-27.

${ }^{56}$ Other pseudonyms make similar claims. Vigilius Haufniensis claims that even the time spent repenting of one's sins is itself a "deficit of action" and therefore a new $\sin (\mathrm{CA}, 117$ 118/SKS 4, 419); see also CUP, 1:526/SKS 7, 478 and SUD, 105/SKS 11, 217. 
${ }^{57}$ Davenport, "The Meaning of Kierkegaard's Choice Between the Aesthetic and the Ethical" p.104

${ }^{58}$ Zahavi, Subjectivity and Selfhood p.130

${ }^{59}$ E.g. Williams, B. (1973) Problems of the Self (Cambridge: Cambridge University Press) pp.43-45

${ }^{60}$ Marks, T.M. (2010), “Kierkegaard's 'New Argument' for Immortality,” Journal of Religious Ethics 38:1, pp.143-86

${ }^{61}$ See also UDVS, 66/SKS 8, 174: "Yet eternity is certainly not like a new world, so that the person who had lived in time according to the ways of time and busyness, when happy and well he had arrived in eternity, now could try his hand at adopting the customs and practices of eternity."

${ }^{62}$ On eternity necessarily appearing as futural, see McTaggart, J.M.E. (1909) "The Relation of Time and Eternity," Mind, 18:1, pp.343-362; and Stokes, P. (forthcoming) "Fearful Asymmetry: Kierkegaard's Search for the Direction of Time."

${ }^{63}$ Beginning with Locke's debate with the Bishop of Worcester on the question of resurrection. See also Perry, J. (1978) A Dialogue on Personal Identity and Immortality (Indianapolis: Hackett); Hick, J. H. (1976) Death and Eternal Life (San Francisco: Harper and Row) pp.278-295; Audi, R. (1976) “Eschatological Verification and Personal Identity” International Journal for Philosophy of Religion 7:4 pp.391-408.

${ }^{64}$ Davenport, "Towards and Existentialist Virtue Ethics" p.273

${ }^{65}$ Davenport, J.J. (forthcoming) "Wholeheartedness, Volitional Purity, and Mortality: A Partial Defense of the Narrative Approach," in: P. Stokes and A. Buben (Eds.) Kierkegaard and Death. 
${ }^{66}$ On the claim that Kierkegaard rejects substantialism, see e.g. Taylor, M.C. (1975)

Kierkegaard's Pseudonymous Authorship: A Study of Time and the Self (Princeton, NJ:

Princeton University Press) p.104 passim; Grøn, A. (2004) “Self and Identity," in: D. Zahavi,

T. Grünbaum and J. Parnas (Eds.) The Structure and Development of Self-Consciousness

(Amsterdam and Philadelphia: John Benjamins) p.131.

${ }^{67}$ Lillegard, N. (2001) "Thinking with Kierkegaard and MacIntyre about the Aesthetic,

Virtue, and Narrative," in: Davenport and Rudd (Eds.), Kierkegaard After MacIntyre, p.223

${ }^{68}$ Stokes, "Anti-Climacus and Neo-Lockeanism"

${ }^{69}$ Locke, J. [1694] (1975) An Essay Concerning Human Understanding, ed. P.H. Nidditch

(Oxford: Clarendon Press) p.344; see also Stokes, "Locke, Kierkegaard, and the

Phenomenology of Personal Identity" pp.648-50. On Locke's subordination of metaphysics to eschatology, see Martin, R. and J. Barresi (2000) Naturalization of the Soul: Self and Personal Identity in the Eighteenth Century (London and New York: Routledge) p.29.

${ }^{70}$ MacIntyre, A. (1981) After Virtue: A Study in Moral Theory (Notre Dame, IN: University of Notre Dame Press) pp.203-4

${ }^{71}$ I don't think we have to accept the theological premises of Kierkegaard's picture to find something compelling in this eschatological picture; a thought like "If I died right this instant, would it all have been worth it?" might be a viable substitute for divine judgment.

${ }^{72}$ Similar to Strawson's “Transience View” (formerly the "Pearl View”); Strawson, G.

(1999) “The Self and the SESMET,” Journal of Consciousness Studies, 6:4, p.129

${ }^{73}$ I should add that I think this mode of self-relation is non-reflective (as argued for in Stokes, Kierkegaard's Mirrors), though nothing hangs on this point here.

${ }^{74}$ Schechtman, The Constitution of Selves pp.73-92 
${ }^{75}$ This paper was made possible by a postdoctoral fellowship from the Independent Danish Research Council - Humanities, hosted at the Søren Kierkegaard Research Centre, University of Copenhagen. I am also grateful to participants at a February 2009 colloquium at the Centre for their valuable comments. 